University of Nebraska - Lincoln

DigitalCommons@University of Nebraska - Lincoln

Agronomy \& Horticulture -- Faculty Publications

Agronomy and Horticulture Department

2002

\title{
Growth response of velvetleaf to three postemergence herbicides
}

Cheryl A. Murphy

University of Nebraska-Lincoln

John L. Lindquist

University of Nebraska-Lincoln, jlindquist1@unl.edu

Follow this and additional works at: https://digitalcommons.unl.edu/agronomyfacpub

Part of the Plant Sciences Commons

Murphy, Cheryl A. and Lindquist, John L., "Growth response of velvetleaf to three postemergence herbicides" (2002). Agronomy \& Horticulture -- Faculty Publications. 408.

https://digitalcommons.unl.edu/agronomyfacpub/408

This Article is brought to you for free and open access by the Agronomy and Horticulture Department at DigitalCommons@University of Nebraska - Lincoln. It has been accepted for inclusion in Agronomy \& Horticulture -Faculty Publications by an authorized administrator of DigitalCommons@University of Nebraska - Lincoln. 


\section{Growth response of velvetleaf to three postemergence herbicides}

Cheryl A. Murphy

Department of Agronomy and Horticulture, University of Nebraska-Lincoln, Lincoln, NE 68583-0817

\section{John L. Lindquist}

Corresponding author. Department of Agronomy and Horticulture, University of Nebraska-Lincoln, Lincoln, NE 68583-0817; jlindquist1@unl.edu

\begin{abstract}
Knowledge of how reduction in the rate of herbicide application or rotation of their mode of action influences weed growth will provide insight into how successful these practices will be in an integrated weed management program. Field experiments were conducted in 1996 and 1997 to quantify velvetleaf growth response to three postemergence herbicides, each with a different mode of action. A monoculture of velvetleaf was treated with halosulfuron, dicamba, and flumiclorac at $0,0.10,0.25$, $0.50,0.75$, and $1.0 \times$ the labeled rate for weed control in corn. Percent plant mortality increased with rate of application; the greatest mortality occurred in flumiclorac treatments in 1996 and in halosulfuron and flumiclorac treatments in 1997. Growth rate temporarily decreased as application rate increased. Maximum height decreased as rate of application increased, with the dicamba treatment resulting in the greatest $(27 \%)$ reduction. Early-season leaf area index decreased with increasing rate of application, the greatest reduction occurring with halosulfuron (1997) and flumiclorac (1996 and 1997) treatments. The number of leaves produced per plant was temporarily reduced by all treatments, but treatment with dicamba later resulted in larger numbers of small leaves. The number of velvetleaf seed capsules produced per surviving plant was not reduced by any treatment, but the number of capsules per square meter was reduced by the $0.5 \times$ rate of flumiclorac (1996) and the $0.5-$ and $1.0 \times$ rates of halosulfuron (1997). Research is needed to evaluate whether the temporary suspension of velvetleaf growth after herbicide treatment is sufficient to prohibit crop yield reduction and velvetleaf capsule production.
\end{abstract}

Nomenclature: Dicamba; flumiclorac; halosulfuron; velvetleaf, Abutilon theophrasti Medic. ABUTH; corn, Zea mays L.

Key words: Reduced rates, mode of action, mortality, height, leaf area index, capsule, sublethal dose, competition.
Herbicides have been effective in reducing the effect of weeds on crop yield for more than 50 yr (Al-Khatib 1996; Holloway and Shaw 1996a, 1996b). However, concerns have arisen over residues in food (Winter 1996), environmental and health hazards of pesticides, declining profitability, and development of herbicide-resistant weed populations (Liebman et al. 2001). Moreover, the recommended rates of herbicides are often higher than what is actually needed for effective weed control (Dieleman and Mortensen 1998). Adjusting the rate of herbicide applied based on the lowest effective application rate is one method by which herbicide use can be reduced (Dieleman and Mortensen 1998; Dieleman et al. 1996). However, if herbicide application rate is minimized, more weeds will survive. Growth, competitive ability, and seed production of weeds surviving a herbicide application are likely to be influenced by that herbicide (Kropff and van Laar 1993). Moreover, herbicides with different modes of action will have different effects on the physiology and competitive ability of plants surviving treatment.

Schmenk and Kells (1998) showed that corn yield loss resulting from nine velvetleaf plants per meter of row was reduced from 35 and $15 \%$ when those nine weeds were survivors of the soil-applied herbicides atrazine or pendimethalin. Weaver (1991) showed that weeds surviving a preemergent application of metribuzin had reduced leaf area and caused substantially less soybean [Glycine max (L.)
Merr.] yield loss when compared with untreated weeds. Ward and Weaver (1996) showed that 50 to $66 \%$ of the recommended rates of metolachlor (preemergence) and imazethapyr (postemergence) reduced the number of berries produced by eastern black nightshade (Solanum ptycanthum Dun.) by 73 to $100 \%$ when compared with an untreated control. Moreover, the number of seeds per berry was reduced by $20 \%$, and the amount of time between emergence and eastern black nightshade flowering was increased. Other authors have shown that weeds surviving reduced herbicide rates produce fewer seeds when compared with uncontrolled weeds (Fawcett and Slife 1978; Henzell et al. 1985; Klingaman et al. 1992; O’Sullivan and Kossatz 1984; Zhang and Cavers 1994a, 1994b).

Weed management decision support systems can be used to help growers select appropriate weed management options (Martin et al. 1998). Within these systems, management options are typically ranked by expected economic return, using the yield loss incurred when weeds are either untreated or exposed to a particular management tactic. Unfortunately, expected yield loss resulting from weeds that survive management is based on the assumption that treated weeds are equally competitive as untreated weeds (Lindquist and Knezevic 2001). Effects of herbicide damage on weed growth, competitive ability, and seed production need to be accounted for to improve the utility of these decision support systems. 
Mechanistic models of interplant competition could be used to explore the effects of weeds damaged by herbicides with different modes of action on crop yield in varying environments. Use of these models for this purpose requires information on how the herbicide influences various aspects of weed physiology and morphology. Mechanistic models are parameterized using data collected on monoculturegrown plants in order to understand the effects of some factor (a herbicide in this case) on the weed without the confounding effects of limiting resources or competition. If the model is constructed so that it accounts for the effects of all appropriate factors on plant growth in monoculture, and the physiological and morphological linkages between factors are correctly accounted for, then the model will be capable of simulating the interactive effects of all factors on crop-weed competition. The objective of this research was to quantify mortality, growth, and relative capsule production in a velvetleaf monoculture in response to variable rates of three common postemergence herbicides, each with a different mode of action.

\section{Materials and Methods}

Field experiments were conducted at the Nebraska Agricultural Research and Development Center near Mead, NE, in 1996 and 1997. Experiments were designed as a randomized complete block with three replicates in 1996 and four replicates in 1997. Experimental treatments included the application of three common postemergence corn herbicides at one out of four (1996) or six (1997) rates. Herbicides of three different modes of action were selected to obtain a range of physiological and morphological responses. The herbicides were halosulfuron, an amino acid biosynthesis inhibitor; dicamba, an auxin-like growth regulator; and flumiclorac, a cell membrane disrupter. Application rates were 0, $0.1,0.25$, and 0.5 times the recommended rate in 1996 and $0,0.1,0.25,0.5,0.75$, and 1.0 times the recommended rate in 1997. The number of treatments was increased in 1997 to allow comparison among the full gradient of rates. Recommended rates for the three herbicides were halosulfuron at $36 \mathrm{~g}$ ai ha $\mathrm{ha}^{-1}$, dicamba at $318 \mathrm{~g}$ ai ha ${ }^{-1}$, and flumiclorac at $3 \mathrm{~g}$ ai ha ${ }^{-1}$. In 1996 an experimental unit consisted of two rows $(0.76 \mathrm{~m}$ apart $)$ of velvetleaf, $4.3 \mathrm{~m}$ long, and a row $(0.76 \mathrm{~m}$ from the velvetleaf row) of corn bordering each side. In 1997 an experimental unit consisted of three rows (0.76 m apart) of velvetleaf, $6 \mathrm{~m}$ long, and a row of corn $1.5 \mathrm{~m}$ from the outer row of velvetleaf. Plants other than velvetleaf were removed throughout the growing season, and irrigation was provided as needed. Velvetleaf seed was planted on May 22, 1996 and May 14, 1997. Emergence occurred on May 27, 1996 and June 1, 1997. When velvetleaf seedlings reached $2 \mathrm{~cm}$, the rows were thinned to one plant every $5 \mathrm{~cm}$ (June 4, 1996, June 10 to 17, 1997). Herbicides were applied on the mornings of June 20, 1996 and June 26,1997 , when velvetleaf plants were $5 \mathrm{~cm}$ tall, and leaves were $4 \mathrm{~cm}$ in diameter.

Two velvetleaf density counts were taken during each season. Plants were counted within a $3.7-\mathrm{m}$ section of each row before treatment application (June 17, 1996 and June 20,1997 ) and again about 1 mo after application (July 12, 1996 and August 2, 1997). Destructive sampling occurred weekly throughout the season (7 and 11 samples in 1996
TABle 1. Monthly precipitation (precip) and mean $\left(T_{\text {ave }}\right)$ daily average temperatures in the months of May, June, and July for 1996, 1997 , and the 30-yr averages.

\begin{tabular}{lcccccccc}
\hline & \multicolumn{2}{c}{1996} & & \multicolumn{2}{c}{1997} & & \multicolumn{2}{c}{30 -yr average } \\
\cline { 2 - 5 } \cline { 7 - 8 } Month & Precip & $T_{\text {ave }}$ & & Precip & $T_{\text {ave }}$ & & Precip & $T_{\text {ave }}$ \\
\hline \multirow{3}{*}{ May } & $\mathrm{mm}$ & $\mathrm{C}$ & & $\mathrm{mm}$ & $\mathrm{C}$ & & $\mathrm{mm}$ & $\mathrm{C}$ \\
June & 178 & 14 & & 21 & 14 & & 117 & 17 \\
July & 69 & 23 & & 73 & 23 & & 155 & 22 \\
\hline
\end{tabular}

and 1997, respectively) by taking one plant from each row, starting the day after application. Height, leaf area, and dry biomass of leaf, stem, and reproductive tissues were measured at each sampling date. The total number of green leaves and capsules was also counted.

Physiological time was quantified by calculating the cumulative growing degree days (GDD) from emergence (Lindquist et al. 1998). Mortality was calculated as (1st count -2 nd count $) / 1$ st count. Average height $(\mathrm{cm})$, leaf area index (LAI) $\left(\mathrm{m}^{2}\right.$ leaf $\mathrm{m}^{-2}$ ground), average number of green leaves, and number of capsules per plant and per square meter were calculated and compared among treatments.

Height growth was quantified by regressing the measured height within each experimental unit on GDD as follows (Christensen 1995):

$$
\text { Height }=C /(1+\exp (A-(B \cdot \mathrm{GDD}))
$$

Estimates of $A$ and $B$ were used to calculate the ratio $A / B$, an estimate of the thermal time required to reach $50 \%$ maximum height ( $C=$ max. height). The $A / B$ and $C$ estimates for each experimental unit were then compared among treatments using analysis of variance. Reproductive period (1997 only) was estimated by subtracting the GDD at flower initiation from that at plant maturity (complete senescence).

An ANOVA was conducted using SAS PROC GLM (SAS 1990), including block, herbicide, rate, year, and their interactions as factors. If treatment by year interactions occurred, analyses were done separately for each year. Because of unequal numbers of experimental units for each treatment in 1996, least square means were compared using the pdiff statement in PROC GLM. The 1997 data were tested by comparing least significant differences.

\section{Results and Discussion}

\section{Mortality}

Seedling mortality within the untreated control was $6 \%$ in 1996 but 51\% in 1997 (Table 2). The greater mortality in 1997 may be partly the result of heterogeneity in the size of individual plants. Plants that were substantially smaller (apparent new emergence) were not counted and were removed during the second count. Therefore, competition among individuals may have contributed to artificial mortality. Differences in growing conditions may also have contributed to variation in mortality among years (Table 1). Precipitation accumulated during May and June was 91 and $35 \%$ of the 30-yr average in 1996 and 1997, respectively. Although these experiments were irrigated in both years, the first application of water did not occur before July 11 . 
TABLE 2. Percent mortality of velvetleaf by herbicide rate and year.

\begin{tabular}{|c|c|c|c|c|c|c|}
\hline \multirow[b]{3}{*}{ Rate $^{\mathrm{a}}$} & \multicolumn{6}{|c|}{ Herbicide } \\
\hline & \multicolumn{2}{|c|}{ Halosulfuron } & \multicolumn{2}{|c|}{ Dicamba } & \multicolumn{2}{|c|}{ Flumiclorac } \\
\hline & $1996^{\mathrm{b}}$ & $1997^{c}$ & 1996 & 1997 & 1996 & 1997 \\
\hline 0.00 & 6 & 51 & 6 & 51 & 6 & 51 \\
\hline 0.10 & 1 & 41 & 4 & 44 & 2 & 43 \\
\hline 0.25 & 4 & 45 & 33 & 41 & 17 & 50 \\
\hline 0.50 & 8 & 62 & 15 & 55 & $50^{*}$ & 55 \\
\hline 0.75 & & 60 & & 53 & & 61 \\
\hline 1.00 & & $72^{*}$ & & 58 & & $64^{*}$ \\
\hline $\mathrm{LSD}^{\mathrm{c}}$ & & 14.8 & & 12.0 & & 11.5 \\
\hline
\end{tabular}

${ }^{\text {a }}$ Fraction of the recommended rate (RR): halosulfuron $\mathrm{RR}=36 \mathrm{~g}$ ai $\mathrm{ha}^{-1}$; dicamba $\mathrm{RR}=318 \mathrm{~g}^{\mathrm{ai} \mathrm{ha}} \mathrm{ha}^{-1}$; flumiclorac $\mathrm{RR}=3 \mathrm{~g}$ ai ha ${ }^{-1}$.

b 1996 data: least square means test used for each herbicide.

c 1997 data: least significant difference test used for each herbicide.

* Significantly different from untreated controls.

Therefore, 1997 was considerably drier during seedling growth, which may have contributed to greater velvetleaf mortality throughout the experiment in that year.

Mortality generally increased as herbicide rate increased (Table 2). The only treatment where mortality was greater than in the untreated control in 1996 was with flumiclorac at the half-rate $(50 \%$ mortality). The $0.5 \times$ rate of flumiclorac also resulted in greater mortality than both the 0.1 $\times(2 \%)$ and the $0.25 \times(17 \%)$ application rates. Mortality was greater than that of the untreated control only at the full recommended rates of halosulfuron and flumiclorac in 1997. The $1.0 \times$ rate of halosulfuron had a greater mortality than did the 0.1 and $0.25 \times$ rates. The $0.5,0.75$, and 1.0 $\times$ rates of flumiclorac had greater mortality than did the $0.1 \times$ rate, and mortality using the full rate $(64 \%)$ was also greater than with the $0.25 \times$ rate. Dicamba applied at the full rate resulted in greater velvetleaf mortality $(58 \%)$ than at the $0.1 \times(44 \%)$ and $0.25 \times(41 \%)$ rates. There was a trend toward lower mortality when herbicides were applied at the $0.10 \times$ rate and occasionally at the $0.25 \times$ rate compared with the controls. Overall, the higher rates ( 0.5 to 1.0 $\times)$ resulted in greater mortality than did the lower rates $(0.1$ to $0.25 \times$ ), with halosulfuron and flumiclorac having the greatest effect, and mortality was greater in 1997 than in 1996.

On the basis of reports of efficacy in the literature, it was expected that velvetleaf seedling mortality would be much greater (70 to $100 \%)$ than that observed here (Buhler et al. 1990; Fielding and Stoller 1990; Hart and Penner 1993; Jordan et al. 1997; Krausz et al. 1995; Mills and Witt 1989; Niekamp and Johnson 2001). The reason for reduced mortality may be that these experiments were conducted in the absence of competition from the crop. Very little research has been conducted to determine the contribution of crop competition to weed seedling mortality after herbicide application. Further research in this area is warranted.

\section{Height}

There was no rate by year interaction affecting the maximum height of velvetleaf, so data were pooled across years. Maximum height decreased as herbicide application rate increased for all three herbicides (Figure 1A). The slope of the maximum height-herbicide rate relationship did not differ
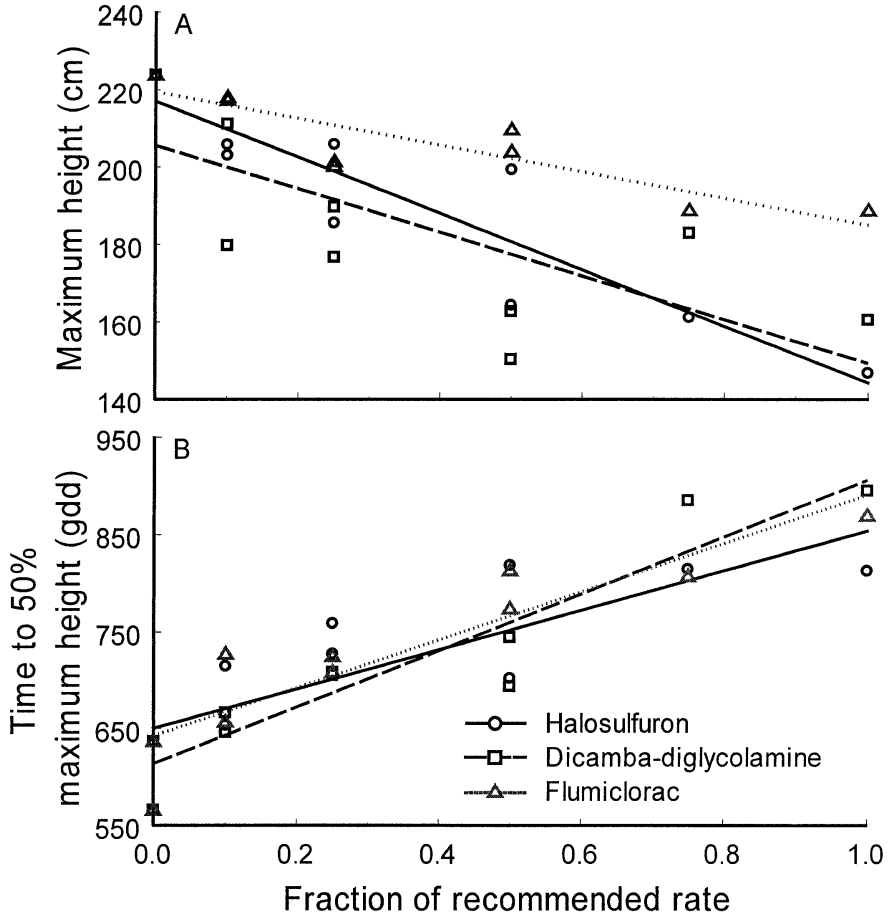

FIGURE 1. (A) Maximum height per plant (cm, $C$ from Equation 1) as influenced by herbicide and rate of application. (B) Thermal time (growing degree days [GDD]) required for velvetleaf to reach $50 \%$ of its maximum height ( $A / B$ from Equation 1). The 1996 and 1997 data were pooled for the analysis, but mean values at each rate are shown. Height $=C /(1+$ $\exp (A-(B \cdot \mathrm{GDD}))$.

except between dicamba and flumiclorac (slope $=-58 \pm$ $20.21 \mathrm{~cm}$; slope $=-37 \pm 8.25 \mathrm{~cm}$, respectively). Thermal time from emergence to $50 \%$ maximum height $(A / B$ in Equation 1) increased as herbicide application rate increased (Figure 1B). Therefore, not only was the maximum height reduced, but the rate of height growth was also reduced. The slope of the relationship in Figure 1B does not differ among herbicides, indicating that the reduction in height growth rate was equivalent for all three herbicides.

\section{Leaf Area Index}

To account for heterogeneity of variances through time, LAI was transformed to its natural log and plotted against cumulative thermal time (GDD). The herbicide by rate and rate by year interaction effects on $\ln (\mathrm{LAI})$ were significant, so the effects of herbicide application rate were analyzed separately for each herbicide and year (Figure 2). All herbicides resulted in a reduction in LAI within $1 \mathrm{wk}$ (GDD $=321$ and 380 in 1996 and 1997, respectively) of application. Higher rates resulted in a greater reduction in LAI that lasted longer. However, after the initial reduction in the rate of leaf area growth, LAI increased so that eventually total canopy LAI did not differ among treatments regardless of herbicide or application rate (Figure 2). The reason for this complete recovery in canopy LAI may be lack of competition from the crop. If so, these results suggest that the crop provides a greater contribution to commonly measured herbicide efficacy than it is given credit for. Further research is needed to evaluate the contribution of crop competition to herbicide performance. 


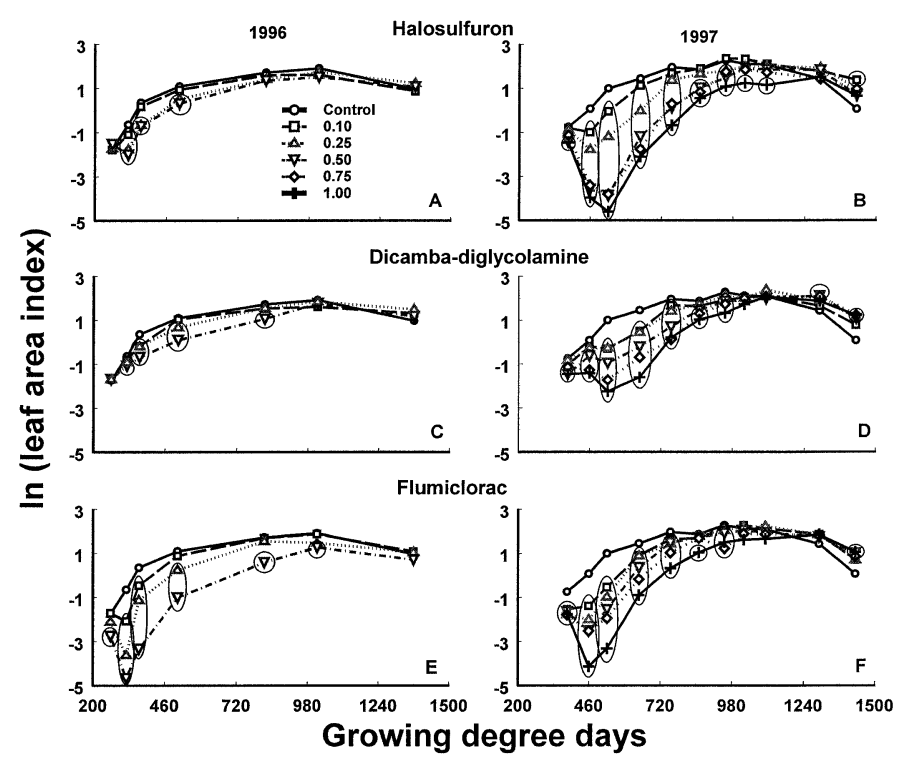

FIGURE 2. Natural log of leaf area index as a function of thermal time from emergence, as influenced by herbicide and rate of application in each year: (A) halosulfuron, 1996; (B) halosulfuron, 1997; (C) dicamba, 1996; (D) dicamba, 1997; (E) flumiclorac, 1996; and (F) flumiclorac, 1997. Circled points indicate that those treatments differed from the untreated control. Data of 1996 were tested using LSM, and 1997 data were tested using LSD, alpha $=0.05$.

\section{Number of Green Leaves}

All herbicides resulted in a reduction in leaf number shortly after treatment in 1996 (Figure 3). The lowest rates of halosulfuron later resulted in a temporary increase in leaf number compared with the control, but the number of leaves of the surviving plants did not differ from the those of the untreated control at the end of the season. Similarly, treatment with dicamba resulted in a greater number of leaves per plant at all application rates, and this difference endured throughout the growing season. Application of flumiclorac resulted in a temporary reduction in the number of leaves per plant, but the number of leaves produced was later equivalent to those of the untreated control plants.

All herbicides resulted in a temporary reduction in number of leaves per plant in 1997, but by the end of the season, plants treated with the higher rates of all herbicides had a greater number of leaves per plant when compared with the untreated control. These results indicate that velvetleaf plants that survive herbicide application will overcompensate by producing a greater number of leaves, and they may obtain an LAI equivalent to that of untreated plants. This again shows that the effect of crop competition on leaf production appears to be far more important than has been recognized.

\section{Reproductive Period}

The reproductive period was calculated as the thermal time (GDD) accumulated between flower initiation and plant maturity in 1997 (Figure 4). Thermal time from emergence to flower initiation varied little among treatments, but the reproductive period was extended as the rate of application increased for all three herbicides $(814,883,870$, and 873 GDD for control, halosulfuron, dicamba, and flumiclorac treated plants, respectively). The slope $(60 \pm 6.1$

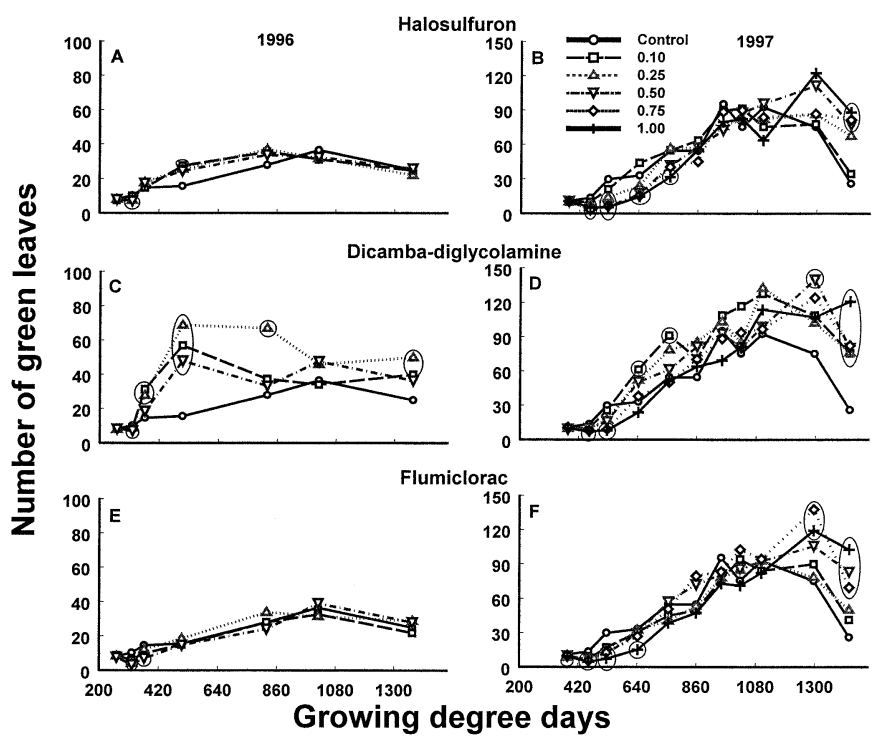

Figure 3. Number of green leaves per plant as a function of thermal time from emergence, as influenced by herbicide and rate of application in each year: (A) halosulfuron, 1996; (B) halosulfuron, 1997; (C) dicamba, 1996; (D) dicamba, 1997; (E) flumiclorac, 1996; and (F) flumiclorac, 1997. Circled points indicate that those treatments differed from the untreated control. Data of 1996 were tested using LSM, and 1997 data were tested using LSD, alpha $=0.05$.

GDD) of the relationship between reproductive period and application rate did not differ among herbicides. Results indicate that one means of recovering from herbicide injury is to increase the length of the growing period. Velvetleaf plants capable of extending their growing season in order to increase leaf production may actually increase their effect on crop production if the period of peak LAI occurs during grain fill.

\section{Capsules Per Plant and Per Square Meter}

The number of capsules produced per surviving velvetleaf plant did not vary with the rate of application of any herbicide (Figures 5A, 5C, and 5E). However, the number of

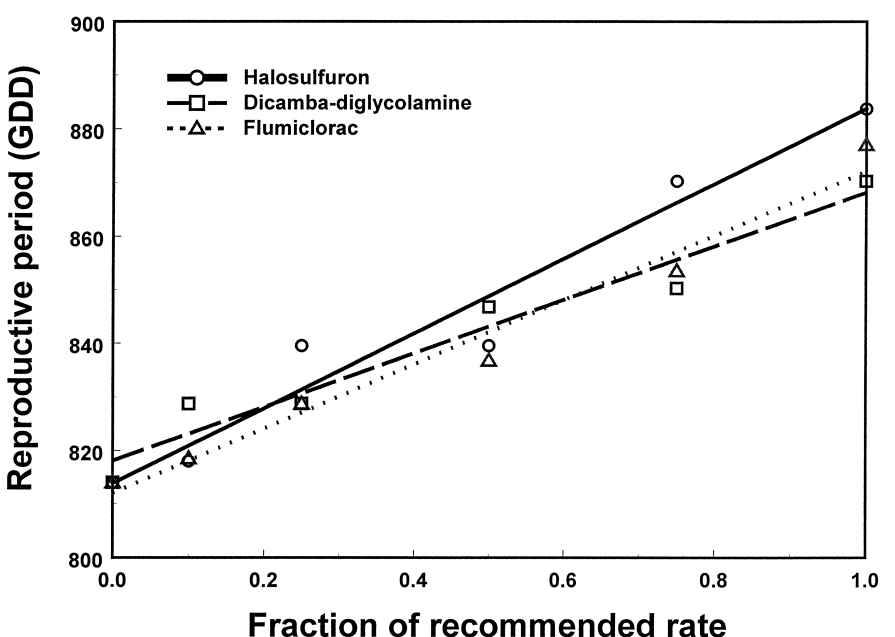

Figure 4. Velvetleaf reproductive period as influenced by herbicide and rate of application in 1997. Reproductive period is the time in growing degree days (GDD) between flower initiation and plant maturity. Slopes $(60 \pm$ 6.1 GDD) did not differ among herbicides at the 0.05 probability level. 


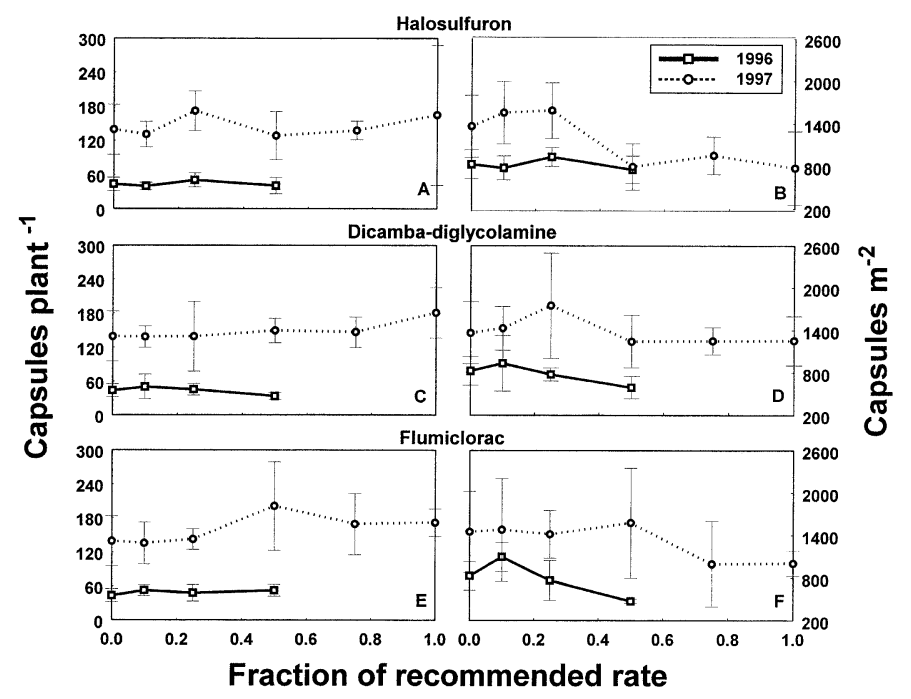

FIGURE 5. Number of velvetleaf seed capsules produced per plant (A, C, E) and number of capsules per square meter $(B, D, F)$ after treatment with halosulfuron, dicamba, and flumiclorac, respectively. Data of 1996 were tested using LSM, and 1997 data were tested using LSD, alpha $=0.05$.

capsules produced per square meter was reduced by $43 \%$ at the 0.5 -times rate of flumiclorac but not at any rate of halosulfuron and dicamba in 1996 (Figures 5B, 5D, and 5F). The number of capsules per square meter was reduced by 42 and $43 \%$ at the 0.5 and $1.0 \times$ rates of only halosulfuron in 1997. Given the full recovery of LAI and the number of leaves produced in both years, the lack of reduction in capsule production per plant may be expected. In fact, there is a trend toward increased capsule production per plant in 1997, particularly at the higher application rates. This trend may contribute to the observed lack of change in capsule production per unit area.

Velvetleaf height and LAI was reduced by herbicide treatment. However, the reduction in LAI was temporary, whereas the height decrease was permanent. Increased rate of application resulted in greater reductions in LAI and increased the time required for recovery. Flumiclorac at $0.5 \times$ the recommended rate resulted in the greatest reduction in LAI and took the longest to recover in 1996, whereas the full rate of halosulfuron resulted in the greatest reduction and recovery period in 1997.

Herbicide application also reduced the number of leaves per plant for 2 to $3 \mathrm{wk}$ after treatment. However, the number of leaves per plant was equivalent to that of the control at the end of the 1996 season and was greater for the higher rates of application of all herbicides at the end of 1997. Late-season differences in the number of leaves were the result of leaf senescence in the control, whereas treated plants continued to produce leaves. Halosulfuron and flumiclorac had a greater effect than dicamba on mortality, earlyseason LAI, and number of capsules per square meter. Although the height of velvetleaf plants sprayed with dicamba was reduced more than that of plants treated with flumiclorac, these plants put more energy into creating a greater number of small leaves.

Given the plasticity of velvetleaf, the developmental delay created within 2 to $3 \mathrm{wk}$ of application becomes important, especially when it is combined with crop competition. Developmental delays in height growth and LAI would give the crop a competitive advantage over the weeds, which could inhibit velvetleaf from recovering later in the season. This advantage would also allow for increased crop leaf area growth that would further place velvetleaf at a competitive disadvantage. Reproductive period and capsule production results show that although capsule production was generally not reduced by herbicide application, higher rates resulted in a developmental delay that resulted in later capsule production. This could result in a reduction in capsule production in environments where an early frost is common.

The influence of these herbicides on velvetleaf growth varies with the rate of application. Therefore, it can be expected that the competitiveness of velvetleaf plants surviving treatment will vary across rate of application. The effect of these survivors on crop yield will ultimately depend upon the crop's competitiveness. The competitive effects of the crop on mortality and subsequent growth may be substantial. Further research is needed to evaluate the growth response of velvetleaf to herbicides used at reduced rates in the presence of crop competition and in different environments. Incorporated into a model for interplant competition, these results may be useful for understanding the contribution of crop competition to weed management and for understanding how weeds will be influenced by various herbicides, rates, and environmental conditions.

\section{Acknowledgments}

This research was supported in part by a USDA-NRICGP grant 97-00785. Contribution of the University of Nebraska Agricultural Research Division (ARD) Journal Series 13454.

\section{Literature Cited}

Al-Khatib, K. 1996. Tulip (Tulipa spp.), daffodil (Narcissus spp.), and iris (Iris spp.) response to preemergence herbicides. Weed Technol. 10: 710-715.

Buhler, D. D., B. D. Philbrook, and E. S. Oplinger. 1990. Velvetleaf and giant foxtail control for solid-seeded soybean production in three tillage intensities. J. Prod. Agric. 3:302-308.

Christensen, S. 1995. Weed suppression ability of spring barley varieties. Weed Res. 35:241-247.

Dieleman, J. A., A. S. Hamill, G. C. Fox, and C. J. Swanton. 1996. Decision rule for postemergence control of pigweed (Amaranthus spp.) in soybean (Glycine max). Weed Sci. 44:126-132.

Dieleman, J. A. and D. A. Mortensen. 1998. Influence of weed biology and ecology on development of reduced dose strategies for integrated weed management systems. Pages 333-362 in J. L. Hatfield, D. D. Buhler, and B. A. Stewart, eds. Integrated Weed and Soil Management. Chelsea, MI: Ann Arbor Press.

Fawcett, R. S. and F. W. Slife. 1978. Effects of 2,4-D and dalapon on weed seed production and dormancy. Weed Sci. 26:543-547.

Fielding, R. J. and E. W. Stoller. 1990. Effects of additives on the efficacy, uptake, and translocation of the methyl ester of thifensulfuron. Weed Sci. 38:172-178.

Hart, S. E. and D. Penner. 1993. Atrazine reduces primisulfuron transport to meristems of giant foxtail (Setaria faberi) and velvetleaf (Abutilon theophrasti). Weed Sci. 41:28-33.

Henzell, R., J. Phillips, and P. Diggle. 1985. Influence of sublethal concentrations of herbicides and growth regulators on mouseearcress (Arabidopsis thaliana) progeny. Weed Sci. 33:430-434.

Holloway, J. C., Jr. and D. R. Shaw. 1996a. Effect of herbicides on ivyleaf morningglory (Ipomoea hederacea) interference in soybean (Glycine max). Weed Sci. 44:860-864.

Holloway, J. C., Jr. and D. R. Shaw. 1996b. Herbicide effects on ivyleaf morningglory (Ipomoea hederacea) and soybean (Glycine max) growth and water relations. Weed Sci. 44:836-841.

Jordan, D., M. McClelland, A. Kendig, and R. Frans. 1997. Monosodium methanearsonate influence on broadleaf weed control with selected postemergence-directed cotton herbicides. J. Cotton Sci. 1:72-75. 
Klingaman, T. E., C. A. King, and L. R. Oliver. 1992. Effect of application rate, weed species and weed stage of growth on imazethapyr activity. Weed Sci. 40:227-232.

Krausz, R. F., G. Kapusta, and J. L. Matthews. 1995. Evaluation of band vs. broadcast herbicide applications in corn and soybean. J. Prod. Agric. 8:380-384.

Kropff, M. J. and H. H. van Laar. 1993. Modelling Crop-weed Interactions. Wallingford, Great Britain/Manila, Philippines: CAB International/International Rice Research Institute. p. 154.

Liebman, M., C. L. Mohler, and C. P. Staver. 2001. Ecological Management of Agricultural Weeds. Cambridge, Great Britain: Cambridge University Press. pp. 1-39.

Lindquist, J. L. and S. Z. Knezevic. 2001. Quantifying crop yield response to weed population: applications and limitations. Pages 205-232 in R.K.D. Peterson and L. G. Higley, eds. Biotic Stress and Yield Loss. Boca Raton, FL: CRC Press.

Lindquist, J. L., D. A. Mortensen, and B. E. Johnson. 1998. Mechanisms of corn tolerance and velvetleaf suppressive ability. Agron. J. 90:787792.

Martin, A. R., D. A. Mortensen, and J. L. Lindquist. 1998. Decision support models for weed management: in-field management tools. Pages 363-369 in J. L. Hatfield, D. D. Buhler, and B. A. Stewart, eds. Integrated Weed and Soil Management. Chelsea, MI: Ann Arbor Press.

Mills, J. A. and W. W. Witt. 1989. Efficacy, phytotoxicity, and persistence of imazaquin, imazethapyr, and clomazone in no-till double-crop soybeans (Glycine max). Weed Sci. 37:353-359.
Niekamp, J. W. and W. G. Johnson. 2001. Weed management with sulfentrazone and flumioxazin in no-tillage soybean (Glycine max). Crop Prot. 20:215-220.

O'Sullivan, P. A. and V. C. Kossatz. 1984. Canada thistle suppression and rapeseed tolerance with dicamba and picloram. Can. J. Plant Sci. 64: 971-977.

[SAS] Statistical Analysis Systems. 1990. SAS Guide for Personal Computers. Version 6, 4th ed. Cary, NC: Statistical Analysis Systems Institute. $1686 \mathrm{p}$.

Schmenk, R. and J. J. Kells. 1998. Effect of soil-applied atrazine and pendimethalin on velvetleaf (Abutilon theophrasti) competitiveness in corn. Weed Technol. 12:47-52.

Ward, K. I. and S. E. Weaver. 1996. Response of eastern black nightshade (Solanum ptycanthum) to low rates of imazethapyr and metolachlor. Weed Sci. 44:897-902.

Weaver, S. E. 1991. Size-dependent economic thresholds for three broadleaf weed species in soybeans. Weed Technol. 5:674-679.

Winter, C. K. 1996. Pesticide residues in foods: recent events and emerging issues. Weed Technol. 10:969-973.

Zhang, J. and P. B. Cavers. 1994a. Effect of herbicide application on fruit characters of Xanthium strumarium L. populations. Weed Res. 34:319326.

Zhang, J. and P. B. Cavers. 1994b. Seedling emergence after maternal bentazon application to 10 common cocklebur (Xanthium strumarium) populations. Can. J. Plant Sci. 74:863-866.

Received July 24, 2001, and approved December 30, 2001. 